Eduardo Garcia Garcia 1 Eduardo Algranti² José Marçal Jackson Filho²

\section{Revista Brasileira de Saúde Ocupacional aprovada para integrar a Coleção SciELO Brasil}

\author{
Revista Brasileira de Saúde Ocupacional approved to \\ integrate the Scientific Electronic Library Online (SciELO) \\ Brazilian Collection
}

1 Editor executivo

${ }^{2}$ Editor científico
Há pouco mais de cinco anos, a RBSO havia perdido todas as suas indexações por quebra de periodicidade e ausências temporárias de publicação. Essa situação afetou a credibilidade do periódico junto à comunidade técnico-científica que se relaciona com o campo da Saúde e Segurança no Trabalho e quase implicou a extinção da revista. Contudo, a necessidade de um lócus referencial para a produção acadêmica da área se fez sentir, levando novamente a Fundacentro a reconhecer a importância de editar, publicar e manter um periódico científico voltado para o campo. Compromissos institucionais foram reassumidos e possibilitaram o desenvolvimento do trabalho de reestruturação da revista visando ao seu fortalecimento e à melhoria contínua da sua qualidade editorial. Esse trabalho vem levando à recuperação e à obtenção de indexações em bases bibliográficas relevantes, culminando agora com o SciELO em cuja página o periódico deverá estar acessível a partir de meados de 2012.

A busca contínua por indexações relevantes é um dos elementos fundamentais para a vitalidade de um periódico científico na atualidade. As bases nacionais e internacionais de indexação ficam cada vez mais criteriosas e exigem diversas qualificações para a aceitação e a permanência dos periódicos em termos de qualidade científica dos artigos publicados, dos procedimentos de avaliação dos manuscritos (avaliação por pares), da agilidade no processo editorial e do mérito científico e da representatividade do corpo editorial das revistas. Estes são os desafios e as responsabilidades que a RBSO vem trabalhando e mantém como perspectiva, fortalecendo ainda mais os compromissos assumidos pela revista com o campo (ALGRANTI, E. et al. A RBSO e seu compromisso com o campo da Saúde do Trabalhador. Revista Brasileira de Saúde Ocupacional, São Paulo, v. 34, n. 120, p. 104-105, jul./dez. 2009. Editorial), entre eles, assegurar a qualidade dos trabalhos publicados, incorporando a abordagem interdisciplinar e agregando novos referenciais teóricos, conceituais e metodológicos, e melhorar a acessibilidade e a divulgação do periódico junto à comunidade científica e à sociedade, propiciando maior difusão dos conhecimentos produzidos pelos pesquisadores da área e subsidiando a discussão de políticas públicas relacionadas ao tema. 